\title{
Talent Performance Analysis Using People Analytics Approach
}

\author{
Fahreza Nasril ${ }^{1}$, Dian Indiyati ${ }^{2}$, Gadang Ramantoko ${ }^{3}$ \\ ${ }^{1,2,3}$ Faculty of Economics \& Business, Telkom University, Bandung, Indonesia \\ fahrezanasril@students.telkomuniversity.ac.id, dianindiyati@telkomuniversity.ac.id, \\ gadangramantoko@telkomuniversity.ac.id
}

\begin{abstract}
The purpose of this study was to answer the research question "How is the prediction of Talent Performance in the following year with the application of People Analytics?" and knowing the description of employees who are potential talents, the resulting performance contributions, to the description of the development and retention efforts needed by Talent in order to be able to maintain their future performance and position as Talents compared to the previous People Analytics method using predictive analysis, namely prediction of Talent Performance in the year next. In this study, data analysis using the Multivariate Logistic Regression method is used to get the Prediction of the Performance of Talents who become the object of research in the form of individual performance quickly and precisely in accordance with the patterns drawn by individual Performance score data in previous years. And can provide insight regarding the projected strategies that need to be done to maintain the improvement of individual talent performance in the years of the assessment period. It also helps management in making decisions about the right Talent development program and determining which Talents are priorities. The population in this study were the talents of employees of PT. Angkasa Pura II (Persero) with a managerial level consisting of: Senior Leader, Middle Leader, and First Line Leader who has a Person Grade (PG) range of 13 to 21. The sample used is Middle Leader level talent with specified criteria and through a process data cleansing. The results of this study indicate that the variable that significantly affects the performance of the following year is the performance of the previous 2 years. Then prediction analysis can be done using these independent variables with the Multinomial Logistic Regression method, and to get prediction results with better accuracy can be done by the Random Forest method.
\end{abstract}

Keywords

talent management; performance; people analytics, predictive analysis

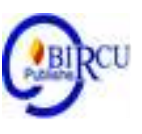

\section{Introduction}

Robbins (2010) a CEO of Cox Communication, in the book The War For Talent with the author Michaels, et al. (2001), stated that Talenta is our only gateway factor to realize our growth vision. There is a close relationship between Talent Management and Performance Management, because the implementation of Talent Management is very much determined by the assessment of individual Talents, starting from the acquisition (recruitment), mapping, development, to Talent evaluation. According to Davis (2014), Talent Management is a well-planned and structured corporate approach to recruiting, retaining, and developing talented people who consistently deliver superior performance. The Talent Management process is to recruit people who are categorized as Talents, keep these people from moving to other companies, and develop people who are categorized as Talents so that they can improve their performance. The author concludes that performance 
as a result of work achievement is deemed necessary to be a concern, where talents who excel in achieving performance should be identified and need to be involved in the Talent Management process. In maintaining talent performance, one of them is by being given an appropriate training program, where Khan (2013) states that job training, training design and job style are the three most significant factors in organizational studies because they contribute to improving employee performance. Ameeq and Hanif (2013) also state that training is the most important part in directly affecting employee performance because it has a significant effect on overall performance and increases efficiency among employees to achieve certain goals.

In the Industry 4.0 era, human resource management, especially talent, was also affected by the rapid development of technology. Human resource management must be able to immediately adjust so as not to be left behind, namely by optimizing the use of technology in various activities to manage HR along with tools that are currently being widely used to help analyze a problem at hand, to help provide insights into decision making by company management, namely using People Analytics approach. Davenport (2019) in Harvard Business Review wrote an article on the function of Human Resources (HR) having the potential to become one of the leaders in the field of analytics who are most able to utilize advanced analytical methods such as predictive and prescriptive models, and even artificial intelligence. People Analytics is a method based on Big Data Analytics which is considered as a new strategic tool that has emerged to advance the transformation of Talent Management and Human Capital Management practices with the resulting benefits (N'Cho, 2017). Marler and Boudreau (2016) state, People Analytics is a practice of Human Resources made possible by information technology that uses descriptive, visual and statistical data analysis related to Human Resources processes, human capital, organizational performance, and external economic benchmarks for builds business impact and enables data driven decision making. It can be concluded that People Analytics is a data-based approach to HR management. Based on the problems that become the phenomenon above, it can be concluded that the use of analytics with the ability at a fairly high level of analysis such as predictive and prescriptive analysis is considered necessary to be implemented because of its benefits for management to make decisions in managing Talenta.

Table 1. Types of Research

\begin{tabular}{|c|l|l|}
\hline No & \multicolumn{1}{|c|}{ Research Characteristic } & \multicolumn{1}{c|}{ Type } \\
\hline 1 & Based on the research objectives & Descriptive \\
\hline 2 & Based on the research paradigm & Positivism \\
\hline 3 & Based on the approach to theory development & Deductive \\
\hline 4 & Based on the research methode & Quantitative \\
\hline 5 & Based on the research strategy & Case Study \\
\hline 6 & Based on the unit of analysis & Individual \\
\hline 7 & Based on the involvement of researchers & Minimal \\
\hline 8 & Based on the research background & Non Contrived \\
\hline 9 & Based on the implementation time & Time Series \\
\hline 10 & Based on the type of investigation & Causal \\
\hline
\end{tabular}

Source: Data Processed (2020) 


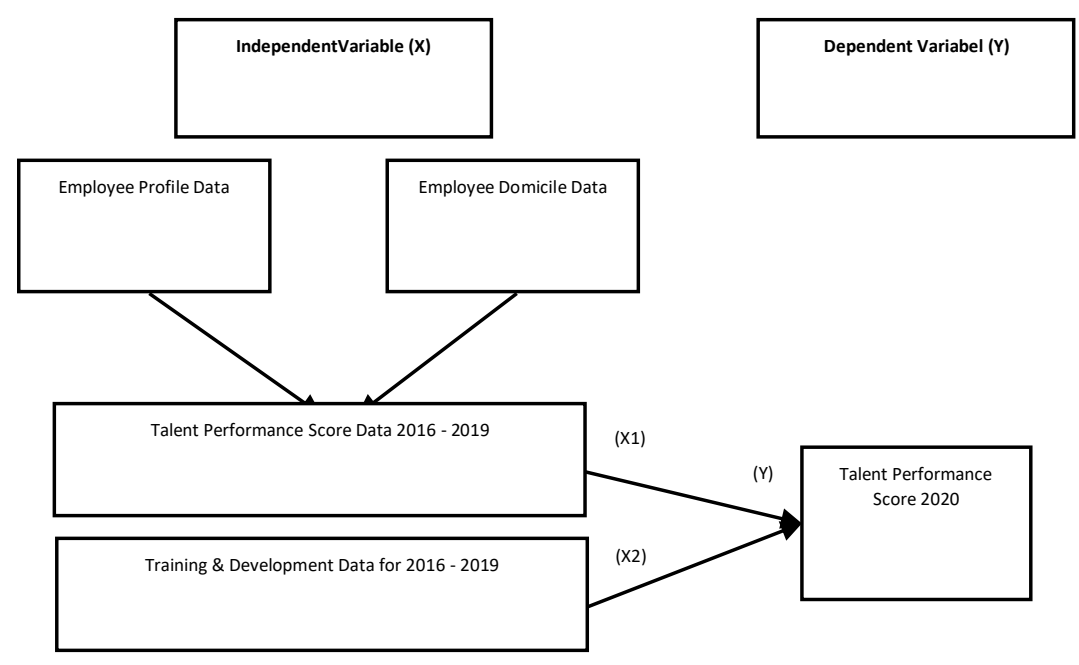

Figure 1. Research Framework

Source: Data Processed (2020)

\section{Review of Literatures}

\subsection{HR Management}

The definition of Human Resource Management (MSDM) according to Mathis \& Jackson (2012) can be interpreted as the science and art that regulates the relationship and role of the workforce to be effective and efficient in using human capabilities in order to achieve goals in each company. Human Resource Management is concerned with a formal design system in an organization to manage human talent to achieve organizational goals (Mathis et. Al, 2015: 2). Human Resource Management is a process for obtaining, training, assessing, compensating employees, and for managing labor, health and safety relationships, as well as matters related to justice (Dessler, 2015). The author concludes that Human Resource Management is a science or way of managing relationships and the role of human resources (HR) that owned by individuals effectively and efficiently and can be used optimally so that can ahieved the goals of the company, employees and society. Human Resource Management is based on the concept that every employee is a human being, not just a machine or considered a just business resource. Human Resource Management is also related to the design and implementation of planning systems, employee arrangement, employee development, career management, talent management, performance evaluation, employee compensation and good employment relations with employees and other related external parties.

Business activities can grow and develop for a long period of time is the goal of each company. Competitiveness, innovation, creativity, and the quality of the products produced must be in accordance with the needs of consumers and can adapt to a dynamic environment (Rosmadi, 2018). Kuswati (2019) stated that in the world of work, employees are required to have high work effectiveness. Organizational effectiveness is usually interpreted as the success achieved by an organization in its efforts to achieve predetermined goals. According to Werdhiastutie et al (2020) the development of human resources should focus more on increasing productivity and efficiency. This can be realized because today's competition, especially among nations, is getting tougher and demands the quality of strong human resources as managers and implementers in an organization or institution. 


\subsection{Talent Management}

Talent Management was first introduced by McKinsey \& Company through one of its studies in 1997. In the following year, Talent Management became a book title co-authored by Ed Michaels et al. Sweem (2013) defines Talent Management as a term for managing talent based on performance and as something that can be distinguished that appears both from humanistic and demographic perceptions. Talent management is a planned and structured corporate approach to recruiting, retaining and developing talented people in organizations (Davis, 2009). The author concludes that Talent Management is an overall process starting from the recruitment and selection, placement, to development and planning for the development of each employee towards career development while meeting the organization or company needs in the short and long term.

From the Talent Management perspective, employee appraisal takes into account two main areas of assessment, namely Performance and Potential. Current employee performance in certain jobs has always been a measuring tool for assessing employee profitability standards, namely how useful and contributing an employee for the organization. However, Talent Management also tries to focus on employee potential, meaning that employee performance in the future will be better if it is accompanied by the development of the right abilities and increased responsibility according to the potential and capabilities portrayed. N'Cho (2017) states, Talent Management is assessed as a systematic use of Human Resource Management (HR) activities to attract, identify, develop, and retain individuals who are considered talented. Talent Management involves many steps including: Talent identification, Talent selection, Talent attraction Talent development, and Talent retention.

\subsection{Performance Management}

Performance Management is considered an important process of organizational effectiveness because the Performance Management process helps employees improve their performance (Gruman \& Saks, 2011). Performance Management can also help organizations or companies to clarify the roles of each employee and ensure the development of each employee on competencies that affect organizational effectiveness. Performance is a term or concept that is often used, especially in the framework of discussion to encourage the success of organizations and Human Resources (HR), where organizations today are faced the challenges of high competition, namely the era of global market competition, advances in IT, competition of human resources competencies that owned, to increasingly critical customer demands.

Bernardin and Russel in Budiarti (2015) state that performance is the result of work performance that has been achieved by an employee in accordance with his/her job function in a certain period. According to Aguinis (2014), Performance Management is a continuous process of identifying, measuring, and developing the performance of individuals and working teams and aligning performance with the strategic goals of the organization. If an organization or company has been able to implement the Performance Management process appropriately, it can provide a reference for the Talent Management process (Khatri et al., 2010). Therefore, defining Talent in a more qualitative form in states the current capabilities and future potential of an employee can support extraordinary performance (Downs \& Swailes, 2013; Heinen \& O'Neill, 2004; Smilansky, 2006). The author conclusion is that performance is the result of work performance which is the achievement of employees in a period according to their main duties and work functions. Performance management through continuous stages includes the identification of company strategic goals that are derived into employee performance targets by 
identification process, setting targets, measuring, employee development, until aligning unit performance targets and company strategic objectives. Therefore, employees who excel in achieving the best performance should be identified through the Performance Management process and need to be involved in the Talent Management process.

\subsection{Training (Training \& Development)}

Training (Training \& Development) is an effort planned by an organization or company to facilitate the learning process by its workers regarding competencies related to the work for which they are responsible. The training should have been well planned by conducting a needs analysis according to the needs of the Organization, Work Unit, and individual employees to make it effective and right on target. At the individual level, the training needs analysis focuses on individual employee needs, competency gaps in soft \& hard skills, job profiles \& job descriptions, and individual job functions therein (referring to the Functional Strategy). Organizations must periodically conduct training to increase knowledge, maintain performance, or rearrange the workforce composition according to the needs of the company's Human Resources (HR) (Hendriyaldi, 2017). Training can be closely related to performance, where training can significantly improve employee performance. From this training will have an impact on improving employee performance which directly affects company performance, as in research (Khan \& Farooq, 2011). Sultana et al. (2012) stated that if an organization invests in training, employees can improve their performance. Khan (2013) states that job training, training design, and job delivery style are the three most significant factors in organizational studies because they contribute to improving employee performance. Ameeq and Hanif (2013) also state that training is the most important part in directly affecting employee performance because it has a significant effect on overall performance and increases efficiency among employees to achieve certain goals.

\subsection{People Analytics}

Marler and Boudreau (2016) state, People Analytics is a practice of Human Resources made possible by information technology that uses descriptive, visual and statistical data analysis related to Human Resources processes, human capital, organizational performance, and external economic benchmarks for builds business impact and enables data driven decision making. People Analytics is an application of the concept of data analysis or data analytics that uses data to provide insights to management in making decisions, both in talent acquisition, retention, placement, promotion, compensation, or workforce and succession planning (Walford-Wright \& Scott-Jackson, 2018). People Analytics can make it easier for companies to describe a problem related to Talenta before making a decision with an approach based on data analysis they have, compared to decision making based on intuition, feelings, hunches, personal experience, and even estimates (N'Cho, 2017). People Analytics is an important tool to strengthen its position as a strategic management partner that does not just appear without going through a series of in-depth analyzes of people in the world of work.

Based on a study of existing theories and their uses, the authors conclude that there are 3 main types of analysis for People Analytics, namely:

1) Descriptive Analysis, helps determine existing conditions and understand what happened and why it happened. Diagnostic analysis can be incorporated into this analysis because of its intended use.

2) Predictive Analysis, helps determine the probability that will happen next based on past information and helps decision making. 
3) Prescriptive analysis, helps find out what should be done in achieving a certain target so that it becomes a recommendation for decisions that need to be done.

\subsection{Predictive Analysis}

Predictive analysis research aims to determine/estimate the probability of individual performance score (Nilai Prestasi Individu) in the following year from the object under study, namely Talent data at the Middle Leader level PT AP II based on information on past data that has been owned. Useful in knowing the efforts that need to be made so that the Talenta can maintain or even improve its performance then it becomes a recommendation for decisions that management needs to retain potential Talents. People Analytics in this study used an Interdependent Multivariate Technique, to test research questions that did not differentiate between independent and dependent variables. The method used is the multinomial logistic regression, that is logistic regression with more than one independent variable to see its effect on the dependent variable.

In representing binary/categorical results, dummy variables are generally used. Logistic regression is a special case of linear regression when the outcome variable is categorical, which can use the odds log as the dependent variable. Simply put, it predicts the likelihood of an event occurring by entering data into a logit function. The Logistic Regression Equation was originally part of a larger class of algorithms known as the Generalized Linear Model (GLM) with the following equation:

$g(E(y))=\alpha+\beta x 1+\gamma x 2$

Where, $\mathrm{g}()$ is the link function, $\mathrm{E}(\mathrm{y})$ is the expectation of the target variable and $\alpha+\beta \mathrm{x} 1+$ $\gamma \times 2$ is the linear predictor $(\alpha, \beta, \gamma$ to be predicted). The role of the link function is to "link" the expectation of $y$ to a linear predictor.

Logistic regression aims to test whether the probability of the dependent variable occurring can be predicted with the independent variable (Ghozali, 2011). Multinomial Logistic Regression Method is used because there is more than one independent variable to see the effect on the dependent variable. The independent variables are the Performance Data 2016 - 2019 as X1 and the Training \& Development Data 2016-2019 as X2. The dependent variable is the Performance Data 2020 as the Y variable. The test aims to determine whether the independent variable being tested has an influence on the dependent variable (Ramli et al., 2013).

\section{Research Methods}

This People Analytics research is based on Big Data Analytics which involves 5V (volume, velocity, variety, value, and veracity) in terms of data collection, analysis, use, and interpretation for various functional divisions, with the aim of gaining useful insights. actionable, create business value, and build competitive advantage. The method used is the prediction analysis of Talent Performance at PT AP II with Multinomial Logistic Regression using Performance data variables that have a significant effect. 
Table 1. Operational Variable

\begin{tabular}{|c|c|c|c|c|}
\hline Variable & Sub Variable & $\begin{array}{c}\text { Operational } \\
\text { Definition } \\
\text { (Indicator) }\end{array}$ & $\begin{array}{c}\text { Item } \\
\text { Number }\end{array}$ & Scale \\
\hline $\begin{array}{c}\text { Independent Variable: } \\
\text { Previous Year Performance } \\
\text { Data (X1) }\end{array}$ & $\begin{array}{c}\text { Talent Performance } \\
\text { Score Data 2016- } 2019\end{array}$ & Performance & 1 & Ordinal \\
\hline & Employee Profile Data & & & \\
\hline & $\begin{array}{c}\text { Employee Domicile } \\
\text { Data }\end{array}$ & & & Ordinal \\
\hline $\begin{array}{c}\text { Independent Variable: } \\
\text { Training \& Development } \\
\text { Data (X2) }\end{array}$ & $\begin{array}{c}\text { Training \& } \\
\text { Development Data } \\
\text { 2016 - 2019 }\end{array}$ & Training & 2 & Ordinal \\
\hline $\begin{array}{c}\text { Dependent Variable: } \\
\text { Next Year Performance } \\
\text { Data (Y) }\end{array}$ & $\begin{array}{c}\text { Talent Performance } \\
\text { Score 2020 }\end{array}$ & Performance & 3 & \\
\hline
\end{tabular}

Source: Data Processed (2020)

\subsection{Population dan Sample}

The study population is the talents of employees of PT. Angkasa Pura II (Persero) with a managerial level consisting of: Senior Leader, Middle Leader, and First Line Leader who has Person Grade (PG) range of 13 to 21. According to May 2020 data, the total Talent at Managerial Level is 1,065 people located work in all areas of the management of PT Angkasa Pura II (Persero). The research sample is Talents at the Middle Leader level who had pass through the data cleansing process with predetermined criteria with a total of 188 people. The sample determination is based on the criteria determined by the author with adjusting the company criteria.

Table 2. Talent Population Data

\begin{tabular}{|c|l|c|c|}
\hline No & Managerial Level & PG & Amount \\
\hline 1 & Senior Leader & $13 \div 14$ & 113 \\
\hline 2 & Middle Leader & $15 \div 17$ & 282 \\
\hline 3 & First Line Leader & $18 \div 21$ & 742 \\
\hline \multicolumn{3}{|c|}{ Total } & 1.137 \\
\hline
\end{tabular}

Source: Data Processed (2020)

Table 3. Talent Sample Data

\begin{tabular}{|l|c|c|}
\hline \multicolumn{1}{|c|}{ Managerial Level } & PG & Amount \\
\hline Middle Leader & $15 \div 17$ & 188 \\
\hline
\end{tabular}

Source: Data Processed (2020) 


\section{Results and Discussion}

\subsection{Data Characteristic}

The characteristics of the data from the sample in this study that have passed the Data Cleansing process as the data attributes are summarized.

Table 5. Data Attribute

\begin{tabular}{|c|c|}
\hline TID & Talent Number \\
\hline PERSONEL_NUMBER & Registration Number of Employees \\
\hline BAND_LEVEL & Job Level Band \\
\hline ORGANIZATIONAL_UNIT & Work Unit \\
\hline POSITION & Position \\
\hline GENDER & Gender \\
\hline TINGKAT_PENDIDIKAN & Education Level \\
\hline LOKASI_JUL_20 & Work Locaiton Per July 2020 \\
\hline PERSON_GRADE_N & $\begin{array}{l}\text { Person Grade in a certain year for } 4 \text { years. There are } 4 \\
\text { attributes, namely PERSON_GRADE_2016 to } \\
\text { PERSON_GRADE_2019 }\end{array}$ \\
\hline PERSON_GRADE_2020 & Person Grade in 2020 \\
\hline USIA_N & $\begin{array}{l}\text { Age in a certain year for } 4 \text { years. There are } 4 \text { attributes, } \\
\text { namely USIA_2016 to USIA_2019 }\end{array}$ \\
\hline MASA_KERJA_N & $\begin{array}{l}\text { The work period in certain years is } 4 \text { years. There are } 4 \\
\text { attributes, namely MASA_KERJA_2016 to } \\
\text { MASA_KERJA_2019 }\end{array}$ \\
\hline TRAINING_N & $\begin{array}{l}\text { Number of Participating in Training and Education in a } \\
\text { certain year for } 4 \text { years. There are } 4 \text { attributes, namely } \\
\text { TRAINING_2016 to TRAINING_2019 }\end{array}$ \\
\hline T_N & $\begin{array}{l}\text { Classification of Participating in Training in a certain } \\
\text { year for } 4 \text { years. If not following = LOW, following } 1 \\
\text { times = MIDDLE, and following more than } 1 \text { times = } \\
\text { HIGH. There are } 4 \text { attributes, namely T_2016 to T_2019 }\end{array}$ \\
\hline NPI_N & $\begin{array}{l}\text { Performance Score in a certain year for } 4 \text { years. There } \\
\text { are } 4 \text { attributes, namely NPI_2016 to NPI_2019 }\end{array}$ \\
\hline KATEGORI_N & $\begin{array}{l}\text { Performance Category in a certain year for } 4 \text { years. } \\
\text { There are } 4 \text { attributes, namely Category_2016 to } \\
\text { Category_2019 }\end{array}$ \\
\hline KELAS_N & $\begin{array}{l}\text { Performance Class in a certain year for } 4 \text { years. There are } \\
4 \text { attributes, namely Class_2016 to Class_2019 }\end{array}$ \\
\hline
\end{tabular}

Source: Data Processed (2020)

\subsection{Results}

In proving the influence between the independent variables, namely the 2016 - 2019 (X1) performance data and the 2016 - 2019 (X2) training data on the dependent variable, namely the 2020 performance data (Y), the following results were obtained: 
1) In forming a prediction model, a significance test is carried out with the Analysis of Deviation Table (ANOVA) on the independent variables which will be used as input variables in making the model with a confidence level of $95 \%$ (p-value $<0.05$ ). Based on the results above, it is obtained that the variable NPI_2017 (p-value 0.0045983) and NPI_2018 (p-value 0.0002729).

$===$ ANOVA $====$

Analysis of Deviance Table (Type II tests)

Response: KELAS_2019

$\begin{array}{llll} & \text { LR Chisq } & \text { Df } & \operatorname{Pr}(>\text { Chisq) } \\ \text { NPI_2017 } & 13.018 & 3 & 0.0045983 * * \\ \text { NPI_2018 } & 19.004 & 3 & 0.0002729 * * *\end{array}$

Signif. codes: $0{ }^{\prime} * * * ' 0.001^{\prime} * *$ ' $0.01^{\prime} *{ }^{\prime} 0.05^{\prime} .{ }^{\prime} 0.1^{\prime \prime}{ }^{\prime} 1$

2) The accuracy level evaluation of the prediction model is seen based on the Error Matrix with a predictive error rate of $29.2 \%$ with an average error of $65.4 \%$, so that the overall level of accuracy is low. Based on the analysis of training set predictions on Performance data in 2019, the correct prediction results were obtained, namely in Performance Class B with a prediction of 34 talents from the actual 65 talents (52.30\%) and $\mathrm{C}$ as many as 99 talents from the actual 115 talents (86.09\%). An example of the 5 Talent prediction results in the table below.

Error matrix for the Linear model on Dataset_U50.csv [**train**] (counts):

Predicted

$\begin{array}{clllll}\text { Actual } & \text { A } & \text { B } & \text { C } & \text { D } & \text { Error } \\ \text { A } & 0 & 6 & 0 & 0 & 100.0 \\ \text { B } & 0 & 34 & 31 & 0 & 47.7 \\ \text { C } & 0 & 16 & 99 & 0 & 13.9 \\ \text { D } & 0 & 1 & 1 & 0 & 100.0\end{array}$

Error matrix for the Linear model on Dataset_U50.csv [**train**] (proportions): Predicted

$\begin{array}{clllll}\text { Actual } & \text { A } & \text { B } & \text { C } & \text { D } & \text { Error } \\ \text { A } & 0 & 3.2 & 0.0 & 0 & 100.0 \\ \text { B } & 0 & 18.1 & 16.5 & 0 & 47.7 \\ \text { C } & 0 & 8.5 & 52.7 & 0 & 13.9 \\ \text { D } & 0 & 0.5 & 0.5 & 0 & 100.0\end{array}$

Overall error: $29.2 \%$, Averaged class error: $65.4 \%$

3) The results of the Error Matrix and performance predictions for 2019 show that the Multinomial Logistic Regression prediction model is less accurate for small data representation, so the Random Forest prediction model will be used to obtain better accurate predictions. The prediction model with Random Forest produces variables of importance which affect the independent variables, namely the performance variables of the previous 2 years that affect the performance of the following year, namely the 
NPI_2018 and NPI_2017 variables. So that it strengthens the significance test generated in the ANOVA above.

Variable Importance

\begin{tabular}{|c|c|c|}
\hline A $B$ & Mean Decrease Accuracy & Mean Decrease Gini \\
\hline NPI_2018 -2.845 .9323 .980 & 20.6 & 30.48 \\
\hline NPI_2017 -6.81 5.64 $20.78-1$ & 17.4 & 28.46 \\
\hline
\end{tabular}

4) The level of accuracy evaluation of the prediction model is seen based on the Error Matrix with a predictive error rate of $-0.1 \%$ with an average error of $0 \%$, so that the overall level of accuracy is high (very accurate).

Error matrix for the Random Forest model on Dataset_U50.csv [**train**] (counts):

Predicted

$\begin{array}{clllll}\text { Actual } & \text { A } & \text { B } & \text { C } & \text { D } & \text { Error } \\ \text { A } & 6 & 0 & 0 & 0 & 0 \\ \text { B } & 0 & 65 & 0 & 0 & 0 \\ \text { C } & 0 & 0 & 115 & 0 & 0 \\ \text { D } & 0 & 0 & 0 & 2 & 0\end{array}$

Error matrix for the Random Forest model on Dataset_U50.csv [**train**] (proportions):

\begin{tabular}{clllll}
\multicolumn{7}{l}{ Predicted } \\
Actual & $\mathrm{A}$ & $\mathrm{B}$ & $\mathrm{C}$ & $\mathrm{D}$ & Error \\
$\mathrm{A}$ & 3.2 & 0.0 & 0.0 & 0.0 & 0 \\
$\mathrm{~B}$ & 0.0 & 34.6 & 0.0 & 0.0 & 0 \\
$\mathrm{C}$ & 0.0 & 0.0 & 61.2 & 0.0 & 0 \\
$\mathrm{D}$ & 0.0 & 0.0 & 0.0 & 1.1 & 0
\end{tabular}

Overall error: $-0.1 \%$, Averaged class error: $0 \%$

Based on the analysis of the training set prediction of the 2019 Performance data, it is concluded that the prediction results show that Random Forest (RF) has a very good level of accuracy. An example of the 5 Talent prediction results in the table below.

Table 6. Example of Prediction Results for Class Performance in 2019

\begin{tabular}{|c|c|c|c|c|c|c|c|c|c|}
\hline TID & $\begin{array}{c}\text { PERSON } \\
\text { EL_NU } \\
\text { MBER }\end{array}$ & $\begin{array}{l}\text { NPI } \\
2019\end{array}$ & $\begin{array}{l}\text { KATEGO } \\
\text { RI_2019 }\end{array}$ & $\begin{array}{c}\text { KELAS } \\
-2019\end{array}$ & glm.A & $\operatorname{glm} \cdot B$ & $\operatorname{glm} . \mathrm{C}$ & glm.D & glm \\
\hline 1 & 20001811 & 111.995 & $\begin{array}{l}\text { SANGAT } \\
\text { BAIK }\end{array}$ & B & $\begin{array}{c}0.041658 \\
852\end{array}$ & $\begin{array}{c}0.227124 \\
248\end{array}$ & $\begin{array}{c}0.723558 \\
826\end{array}$ & $\begin{array}{c}0.007658 \\
074\end{array}$ & $\mathrm{C}$ \\
\hline 2 & 20002425 & 110.6 & $\begin{array}{c}\text { SANGAT } \\
\text { BAIK }\end{array}$ & B & $\begin{array}{c}0.016274 \\
185 \\
\end{array}$ & $\begin{array}{c}0.319255 \\
2 \\
\end{array}$ & $\begin{array}{c}0.657857 \\
549\end{array}$ & $\begin{array}{c}0.006613 \\
066\end{array}$ & $\mathrm{C}$ \\
\hline 3 & 20002934 & 109.604 & BAIK & $\mathrm{C}$ & $\begin{array}{c}0.018617 \\
455\end{array}$ & $\begin{array}{c}0.306772 \\
414\end{array}$ & $\begin{array}{c}0.667813 \\
91 \\
\end{array}$ & $\begin{array}{c}0.006796 \\
222\end{array}$ & $\mathrm{C}$ \\
\hline 4 & 20003634 & 112.883 & $\begin{array}{l}\text { SANGAT } \\
\text { BAIK }\end{array}$ & B & $\begin{array}{c}0.038358 \\
534\end{array}$ & $\begin{array}{c}0.705583 \\
161\end{array}$ & $\begin{array}{c}0.234796 \\
309\end{array}$ & $\begin{array}{c}0.021261 \\
996\end{array}$ & B \\
\hline 5 & 20002042 & 102.291 & BAIK & $\mathrm{C}$ & $\begin{array}{c}0.008098 \\
189\end{array}$ & $\begin{array}{c}0.348823 \\
481\end{array}$ & $\begin{array}{c}0.637870 \\
239\end{array}$ & $\begin{array}{c}0.005208 \\
09\end{array}$ & $\mathrm{C}$ \\
\hline
\end{tabular}

Source: Data Processed (2020) 
5) The Predict process for Talent Performance Class in 2020 requires a dummy variable, therefore it is necessary to create a dummy file to make predictions which will result in predictive data for the overall Talent Performance in 2020 which shows that 134 Talents $(71.28 \%$ ) can maintain Performance, 27 Talents $14.36 \%$ ) cannot maintain Performance because there is a decrease in Performance Classes (from A to B, A to C, and $\mathrm{B}$ to $\mathrm{C})$, and 27 Talents $(14.36 \%)$ can increase Performance due to an increase in Performance Classes from C to B and D to C.

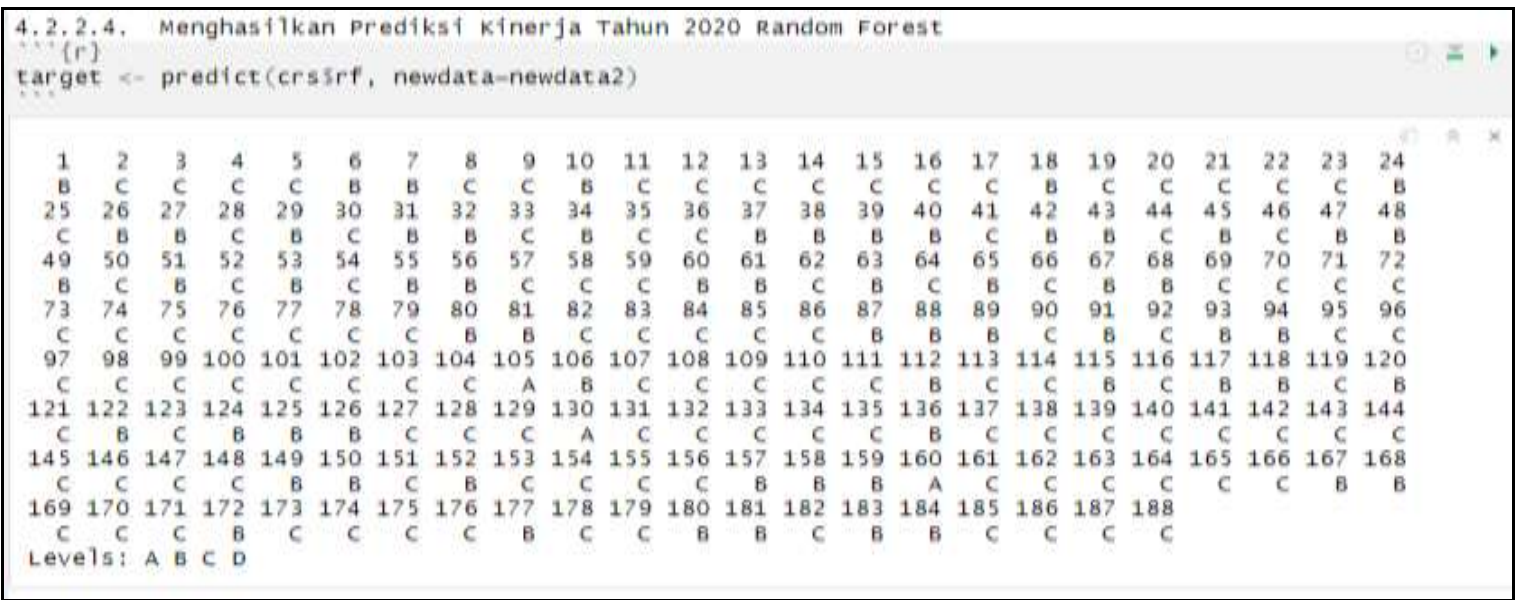

Figure 1. Performance Predictions in 2020

Source: Data Processed (2020)

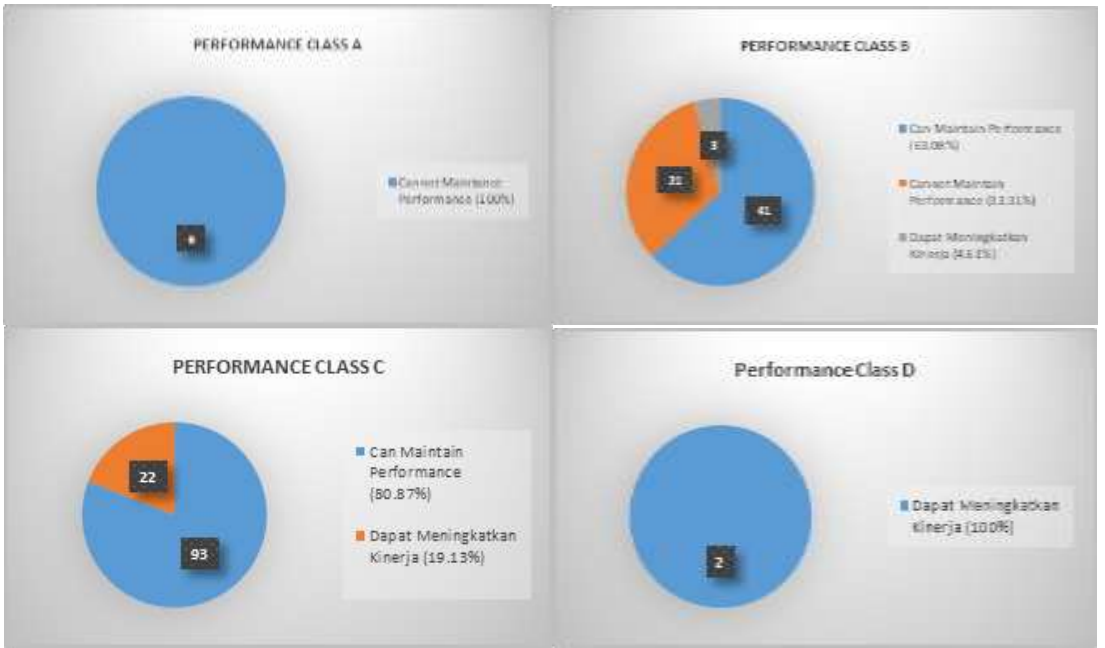

Figure 2. Prediction Results of Each Talent Performance Class in 2020

Source: Data Processed (2020) 


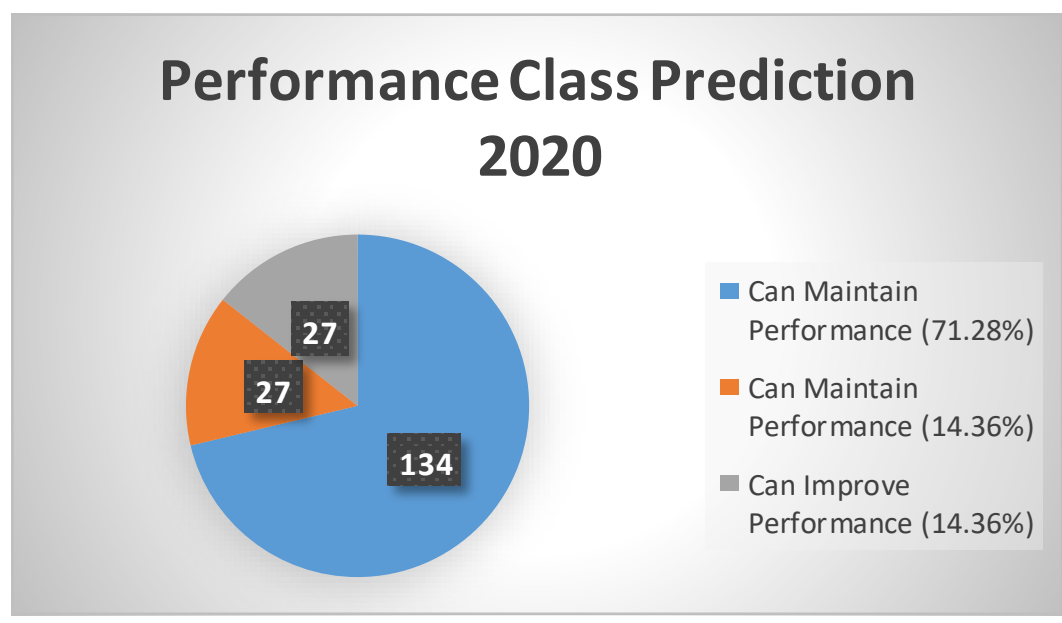

Figure 3. Prediction Results of Talent Performance Class in 2020

Source: Data Processed (2020)

The author concludes that there is a probability that Talenta can maintain Performance in Performance Classes B and C. In addition, there is a decrease in Performance Classes from A to $\mathrm{B}$ and $\mathrm{C}$, from $\mathrm{B}$ to $\mathrm{C}$, which means that Talents cannot maintain the performance achieved in the previous year. In addition, there is also an increase in Performance Class from B to C, as well as from D to B and C, which means that Talents can maintain, and even increase, Performance beyond the previous year. This condition can occur because of a different condition from the Talent depending on the time, responsibility, authority, support, and standards \& criteria at that time. There are other factors that can also change the condition, namely the efforts made by Talent in achieving the specified performance targets or even the right efforts and support from the company as needed in developing the Talent. This supports Arini (2015), performance is an achievement of the work of a person or group of people in an organization and a certain period of time in accordance with the scope of responsibility and authority of each as an effort to achieve organizational goals and is carried out in accordance with morals and ethics and legal without breaking the law.

Based on the significance test, the performance data has a significant effect on the prediction of the next year's performance when using data from the previous 2 years, not for more than the previous 2 years. Although in form and information performance data is the same type of data that is only distinguished from the year it was obtained, but with differences in time and conditions, the effect can also be different. This is supports Indrawati's (2015:124) statement, namely that a variable is anything that has a value and that value can vary and can change. Sekaran \& Bougie (2010) also states that the value of an object at different times can be different, and different objects at the same time can have different values. Other Talenta Profile data do not have a significant effect on the 2020 Performance prediction, but can be used as supporting data for additional information to enrich the analysis of Talenta.

Training data (training \& development) was found to have no significant effect, so it is not in line with the research results of Khan (2013), Sultana et al. (2012), Khan \& Farooq (2011), as well as Ameeq and Hanif (2013) which state that providing training as a company investment to employees will have a positive or very strong effect on improving employee performance, as well as company performance. In data analysis, the quantity of training alone is not significant to improve talent performance, so it must more pay attention to the quality of training and suitability of talent needs in an integrated manner with a good planning program through Training Needs Analysis, as well as effective implementation and evaluation. 


\section{Conclusion}

People Analytics in the form of predictive analysis of talent performance in 2020 can be carried out using the performance variable of the last 2 years as the independent variable which significantly affects the dependent variable. The method used is Multinomial Logistic Regression and enhanced with Random Forest to get a better level of accuracy. The prediction results illustrate the performance contribution generated by talents in the following year in the form of performance that can be maintained, cannot be maintained (there is a decrease in performance), and can be increased beyond their achievements in the previous year so that it becomes information for talents that are considered potential for the company, namely talents who can maintain and can improve performance so that it contributes to company performance as well.

Talent development efforts and retention strategies that are considered important to be carried out are always maintaining the annual performance of the talents so that they can always be achieved properly so that the talents can maintain and improve their performance in the future. Based on the predicted results, talents still have the opportunity to get their actual performance even though it is different from the predicted results from the efforts made by the company and the talent itself which depends on the situation and conditions. As an added benefit of the predicted results by achieving the research objectives, decision making related to talent development and retention strategies can be better considered and planned more objectively and effectively with the main priority being potential talents.

\section{References}

Arfan Aruan, D. (2013). Pengaruh Pelatihan Kerja dan Motivasi Terhadap Kinerja Karyawan PT. Sucofindo (Persero) Surabaya. Jurnal Ilmu Manajemen (JIM), 1(2).

Ataunur, I., \& Ariyanto, E. (2016). Pengaruh Kompetensi dan Pelatihan Terhadap Kinerja Karyawan PT. Adaro Energy Tbk. Telaah Bisnis, 16(2).

Ben-Gal, H. C. (2018). An ROI-based review of HR analytics: practical implementation tools. Department of Industrial Engineering and Management, Afeka College of Engineering, Tel Aviv, Israel and School of Management, San Jose State University, San Jose, California, USA. Personnel Review Vol. 48 No. 6, 2019 pp. 1429-1448 (C) Emerald Publishing Limited.

Berlian, Y. S. (2019). Human Capital: People Analytic. [online]. https://yusufsaefulberlian.wordpress.com/2019/09/17/people-analytic/ [15 Maret 2020].

Bimasatria. (2019). “Apa Yang Dimaksud Dengan Kapabilitas?” dictio.id [online] https://www.dictio.id/t/apa-yang-dimaksud-dengan-kapabilitas/ [3 Mei 2019]

Bhattacherjee, A. (2012). Social science research: Principles, Methods, and Practices. Textbooks Collection. 3. http://scholarcommons.usf.edu/oa_textbooks/3

Brudan, A. (2010). Rediscovering Performance Management: Systems, Learning And Integration. Measuring Business Excellence. 14. 109-123. 10.1108/13683041011027490.

Cascio, W. F., \& Boudreau, J. W. (2016). The search for global competence: From international HR to talent management. Journal of World Business, 51(1), 103-114.

Chambers, E. G., Foulon, M., Handfield-Jones, H., Hankin, S. M., \& Michaels, E. G. (1998). The war for talent. McKinsey Quarterly, 44-57. 
CRM-Indonesia (2018). Apa itu People Analytic?, [online], http://crm-indonesia.com/apaitu-people-analytic/ [15 Maret 2020].

Dahlbom, P., Siikanen, N., and Sajasalo, P., \& Jarvenpää, M. (2019). Big data and HR analytics in the digital era. School of Business and Economics, Jyväskylä University, Jyväskylä, Finland and School of Accounting and Finance, University of Vaasa, Vaasa, Finland. Baltic Journal of Management Vol. 15 No. 1, 2020 pp. 120-138 (C) Emerald Publishing Limited.

Darman. Kinerja (2016). Pegawai [online], http://theorymanajemendanorganisasi.blogspot.com/2016/01/kinerja-pegawai.html [6 Mei2020].

Davenport, T. (2014). Big Data at Work: Dispelling The Myths, Uncovering The Opportunities. Harvard Business Review Press.

Dokumen Perusahaan : Annual Report PT Angkasa Pura II (Persero) Tahun 2019.

Dokumen Perusahaan : Human Capital Masterplan PT Angkasa Pura II (Persero) Tahun 2016-2020.

Dokumen Perusahaan : Rencana Jangka Panjang Perusahaan PT Angkasa Pura II (Persero) Tahun 2016-2020.

Eduardo Valencia (2018)., People Analytics. Data and Text Analytics for Human Resources, Lean Publishers, Canada, p.iii.

Endratno, H. (2013). Talent Management Dalam Meningkatkan Kinerja Organisasi. Sustainable Competitive Advantage (SCA), 1(1).

Ferrar, J. (2019). How Can I Be More Successful At People Analytics. [online]. https://www.linkedin.com/pulse/how-can-i-more-successful-people-analyticsjonathan-ferrar?articleId=6534785996389699584\#comments6534785996389699584\&trk=public_profile_article_view [15 Maret 2020].

Hanif, T. T., Adiwijaya, A., \& Al-Faraby, S. (2017). Analisis Churn Prediction Pada Data Pelanggan Pt. Telekomunikasi Menggunakan Underbagging Dan Logistic Regression. eProceedings of Engineering, 4(2).

Hendriyaldi, H. (2017). Pengaruh Pelatihan Dan Motivasi Terhadap Produktivitas Manajer PT. Sucofindo (Persero) Pusat. Jurnal Benefita: Ekonomi Pembangunan, Manajemen Bisnis \& Akuntansi, 2(3), 255-266.

Keerthi, P. L. (2018). The Process of People Analytics. Research Scholar, Department of Business Management, Sri Venkateswara University, Tirupati, India.

Kuswati, Y. (2019). Motivation Role in Improving Work Effectiveness. Budapest International Research and Critics Institute-Journal (BIRCI-Journal). P. 281-288.

Larivière, B., \& Van den Poel, D. (2005). Predicting customer retention and profitability by using random forests and regression forests techniques. Expert Systems with Applications, 29(2), 472-484.

Leonardi, P., \& Contractor, N. (2018). Better people analytics. Harvard Business Review, 96(6), 70-81.

Mathis, R. L., Jackson, J. H., \& Valentine, S. R. (2015). Human resource management: Essential perspectives. Cengage Learning.

Mayo, A. (2018). Applying HR analytics to talent management. Strategic HR Review.

Michaels, E., Handfield-Jones, H., \& Axelrod, B. (2001). The war for talent. Harvard Business Press.

Mozael, B. M. (2015). Impact of training and development programs on employee performance. International Journal of Scientific and Research Publications, 5(11), 37-42. 
Pattiasina, M., Roring, M., \& Rumawas, W. (2016). Pengaruh Kompetensi Sumber Daya Manusia Terhadap Kinerja Karyawan PT. Bank Tabungan Negara, Tbk. Kantor Cabang Manado. Jurnal Administrasi Bisnis, 4(2).

Prastya, I. (2020). "Pengertian Kinerja?" ayoksinau.com. [online] https://www.ayoksinau.com/pengertian-kinerja/ [20 April 2020]

Rahman, A. A., Ng, S. I., Sambasivan, M., \& Wong, F. (2013). Training and Organizational Effectiveness: Moderating Role of Knowledge Management Process. European Journal of Training and Development.

Rosmadi, M.L.N. (2018). Factors in Developing Creative Industry. Budapest International Research and Critics Institute-Journal (BIRCI-Journal). P. 64-69.

Sequeira, A., Attupuram, P. J., \& Gopalakrishnan, S. (2015). Talent acquisition process in a multinational company: A case study. Social Science Research Network.

Sivathanu, B., \& Pillai, R. (2019). Technology and talent analytics for talent managementa game changer for organizational performance. International Journal of Organizational Analysis.

Snell, A. (2011). Developing talent intelligence to boost business performance. Strategic HR Review Vol. 10 NO. 2 2011, pp. 12-17, @Emerald Group Publishing Limited.

Soedijono, B. (2014) Analisis Numerik. In: Galat dan Perambatannya. Universitas Terbuka, Jakarta, pp. 1-29. ISBN 9790111916

Sultana, A., Irum, S., Ahmed, K., \& Mehmood, N. (2012). Impact of training on employee performance: A study of telecommunication sector in Pakistan. Interdisciplinary Journal of contemporary research in business, 4(6), 646-661.

Sudarmanto. (2009). Kinerja dan Pengembangan Kompetensi SDM. Cetakan Keempat, Mei 2018. Pustaka Pelajar, Yogyakarta. ISBN: 978-602-8479-58-5.

Swailes, S., \& Blackburn, M. (2016). Employee reactions to talent pool membership. Employee Relations, 38(1), 112-128.

Tetik, S. (2017). Talent Management: A Review of Theoretical Perspectives and a Guideline for Practioners. Nile Journal of Business and Economics, 2(4), 40-56.

Thunnissen, M. (2016). Talent management: For what, how and how well? An empirical exploration of talent management in practice. Employee Relations, 38(1), 57-72.

Walford-Wright, G., \& Scott-Jackson, W. (2018). Talent Rising; people analytics and technology driving talent acquisition strategy. Strategic HR Review.

Werdhiastutie, A., et al. (2020). Achievement Motivation as Antecedents of Quality Improvement of Organizational Human Resources. International Research and Critics Institute-Journal (BIRCI-Journal). P. 747-752.

Wulandari, \& Alamanda (2012). Pengaruh Pelatihan dan Disiplin Kerja Terhadap Kinerja Karyawan Pada Yayasan Pendidikan Telkom. Jurnal Banking dan Manajemen Review Ekuitas Vol 1 No 12012. 